Гандзюк Костянтин Андрійович аспірант кафедри публічної політики, Навчально-науковий інститут публічного управління та державної служби Київського національного університету імені Тараса Шевченка, вул. Академіка Ромоданова, 12/2, м. Київ, 02000, тел.: (067) 209-37-63, e-mail: gandziuk_kostiantyn@ukr.net, https://orcid.org/ 0000-0002-5576-9867

\title{
ТЕОРЕТИЧНІ ВИТОКИ КОНЦЕПЦІї НОВОЇ ПУБЛІЧНОЇ СЛУЖБИ
}

Анотація. У статті проведене дослідження провідних теоретичних джерел концепції нової публічної служби Дженет та Роберта Денхардтів. 3'ясовано, що до наукових передумов цієї концепції належать: теорія демократичного громадянства; теорія громадянського суспільства; організаційний гуманізм та нове публічне адміністрування; постмодерне державне управління. Виявлено, що нова публічна служба запозичує з теорії демократичного громадянства розуміння громадянства як здатності особистості впливати на політичну систему, брати активну участь у політичному житті. При цьому альтруїзм сприймається не як самопожертва, а усвідомлення того, що реалізація загальних інтересів вище за індивідуальні потреби. До такого висновку може прийти громадянин, який відчуває свою єдність 3 локальною громадою та громадянським суспільством. Відповідно, наступне ідейне джерело концепції Денхардтів - це концепт громадянського суспільства. Популяризація цього феномену у теорії і практиці свідчить про його зростаючу соціально-політичну роль. Його ключове завдання - подолання конфліктів завдяки широкій комунікації. Організаційний гуманізм та нове публічне адміністрування збагачують науковий конструкт Денхардтів критикою бюрократії та пошуком альтернативних підходів до керівництва та організації в публічній царині, які б сприяли проактивній позиції державного службовця через залученість до процесу вироблення публічних рішень та відповідальність, вимірювання результатів та належну мотивацію. Постмодерні студії змушують замислитися над гіперраціоналізацією усіх суспільних сфер, у тому числі публічного управління. Постмодерне публічне управління усвідомлює, що реальність має враховувати емоційну та почуттєву складову, так само як і раціональні показники, а дискурсивні практики повинні стати основою вироблення конструктивного публічного рішення.

Ключові слова: нова публічна служба, постмодернізм, громада, громадянське суспільство, демократичне громадянство, організаційний розвиток, уряд, дискурс. 
Gandziuk Kostiantyn Andriiovych $\mathrm{PhD}$ student of Public Policy Department, Educational and Scientific Institute of Public Administration and Civil Service Taras Shevchenko National University of Kyiv, 12/2, Academician Romodanov St., Kyiv, 02000, tel.: (067) 209-37-63, e-mail: gandziuk_kostiantyn@ukr.net, https://orcid.org/ 0000-0002-5576-9867

\section{THEORETICAL ORIGINS OF THE NEW PUBLIC SERVICE CONCEPT}

Abstract. The article examines the leading theoretical sources of the concept of a new public service by Janet and Robert Denhardt. It was found out that the scientific preconditions of this concept include democratic citizenship theory; civil society theory; organizational humanism and new public administration; postmodern public administration. It was found out that the new public service borrows from the theory of democratic citizenship the understanding of citizenship as the ability of an individual to influence the political system, to take an active part in political life. At the same time, altruism is perceived not as self-sacrifice, but as understanding that the realization of common interests is higher than individual needs. This conclusion can be reached by a citizen who feels his unity with the local community and civil society. Accordingly, the next ideological source of the Denhardts' concept is the concept of civil society. The popularization of this phenomenon in theory and practice indicates its growing sociopolitical role. Its key task is to overcome conflicts through broad communication. Organizational humanism and the new public administration enrich Denhardts' scholarly construct by criticizing the bureaucracy and seeking alternative approaches to leadership and organization in the public sphere that would promote the proactive position of the civil servant through involvement in public decision-making and accountability. Postmodern studies make us think about the hyper-rationalization of all social spheres, including public administration. Postmodern public administration recognizes that reality must consider the emotional and sensory components, as well as rational indicators, and discursive practices must be the basis for making a constructive public decision.

Keywords: new public service, postmodernism, community, civil society, democratic citizenship, organizational development, government, discourse.

Постановка проблеми. Розробка нових наукових концепцій та теорій у галузі публічного управління та адміністрування розв'язує проблему модернізації та оновлення системи державного управління та державної служби. Концепція нової публічної служби Дженет та Роберта Денхардтів пропонує окрему візію перспектив розвою публічного сектору, яка долає недоліки класичного публічного адміністрування на нового публічного менеджменту. 
Аналіз останніх досліджень та публікацій. Серед фахівців, які досліджують науковий конструкт Денхардтів у цілому або його окремі аспекти, можна виділити таких дослідників, як С. Левченко, Д. Неліпа, В. Солових, О. Хорошенюк тощо. Однак, слід наголосити, що їхні теоретичні напрацювання не містять розвідок, присвячених пошукам наукових витоків концепції нової публічної служби.

Мета статті: виявити та проаналізувати теоретичні джерела концепції нової публічної служби Денхардтів.

Виклад основного матеріалу. Дженет та Роберт Денхардти обгрунтовують власну концепцію не лише практичними передумовами, але й знаходять потужний теоретичний фундамент, який $є$ науковим контекстом оформлення ключових положень нової публічної служби. До теоретичних передумов даної концепції можна віднести: 1) теорію демократичного громадянства; 2) теорію громадянського суспільства; 3) організаційний гуманізм та нове публічне адміністрування; 4) постмодерне державне управління. Деталізуємо ідейні взаємозв'язки між цими теоретичними напрямами та концепцією нової публічної служби.

\section{Демократичне громадянство.}

Занепокоєння щодо громадянства та демократії є особливо важливими та помітними у соціально-політичній теорії, що проявляється вимогою пожвавлення та активізації громадянства $[1 ; 2 ; 3]$. Але на громадянство можна дивитися по-різному. Перша позиція зосереджується на правах та обов'язках громадян, визначених правовою системою, тобто громадянство розглядається як правовий статус. Альтернативна, ширша точка зору розглядає громадянство як занепокоєння більш загальними питаннями, що стосуються характеру членства у політичній спільноті, включаючи такі питання, як права та відповідальність громадян, незалежно від їх правового статусу [4]. 3 цієї точки зору, громадянство стосується здатності особистості впливати на політичну систему, передбачає активну участь у політичному житті. Останній погляд імпонує Дженет та Роберту Денхардтам.

Крім цих визначень, існують різні способи зрозуміти, що пов'язано 3 демократичним громадянством. Наприклад, можна стверджувати, що уряд існує, перш за все, для того, щоб просувати економічні інтереси громади та окремих людей у межах громади. У цьому випадку держава та ставлення громадян до держави мають базуватися просто на ідеї власних інтересів. Згідно з М. Санделом, переважаюча модель відносин між державою та громадянами фактично базується на ідеї, що уряд існує для того, щоб громадяни могли робити вибір, який відповідає їхнім особистим інтересам, гарантуючи певні процедури (наприклад, голосування) та індивідуальні права [3]. Роль уряду полягає в тому, щоб взаємодія індивідуальних особистих інтересів відбувалася вільно і справедливо. Хоча альтруїзм часто входить у громадські обговорення, політичні інститути мають бути спроектовані таким чином, щоб мінімізувати їх покладання на альтруїстичну 
поведінку [2].

Інші стверджують, що політичний альтруїзм, або те, що Дж. Менсбрідж називає «громадським духом», відіграє важливу роль у процесі демократичного управління. Так, М. Сандел пропонує альтернативний погляд на демократичне громадянство, в якому окремі особи набагато активніше залучаються до управління. Громадяни дивляться за межі власних інтересів на широкі суспільні потреби, приймаючи більш широку та довгострокову перспективу, яка вимагає знання суспільних справ, а також почуття приналежності, турботи в цілому та морального зв’язку з громадою, доля якої на кону [3]. Дж. Менсбрідж стверджує, що такий погляд на громадянство забезпечує певний «клей», який утримує політичну систему вкупі [2].

Однак, Дж. Менсбрідж вказує, що нестримний альтруїзм не обов’язково є благом. Існує ймовірність того, що політичні еліти можуть маніпулювати громадським духом шляхом індоктринації чи харизми, обмежуючи можливості його вираження або структуруючи громадські дебати таким чином, щоб заборонити виклики їхній владі.

Громадський дух потрібно живити і підтримувати, і цьому може сприяти постійна увага до принципів справедливості, участі громадськості та міркувань. Почуття справедливості викликає сильні емоції у тих, хто відчуває погане поводження або експлуатацію, і їх опір часто може стати досить сильним. 3 іншого боку, політична система, яка, здається, має намір сприяти справедливості, може викликати прихильність та причетність. Участь - це другий засіб просування громадського духу. Ті, хто бере участь у прийнятті рішень, краще відчувають ці рішення i, швидше за все, допоможуть у їх реалізації. Але варто пам'ятати, що участь може бути побудована таким чином, щоб викликати у людей помилкове почуття причетності, тому іiі необхідно збалансувати 3 умовами відкритого обговорення та дискурсу. Роздуми можуть прояснити, а іноді i поліпшити сприйняття відмінностей. Обговорення може надати спільну інформацію, щоб люди, принаймні, починали «з однієї сторінки». Це може створити почуття солідарності та відданості рішенням, які можуть бути запропоновані.

Громадянське суспільство.

Корені нової державної служби також можемо знайти у важливих дискусіях про громаду та громадянське суспільство. Поширений нинішній інтерес до цього соціально-політичного інституту $\epsilon$ цікавим явищем i пов'язаний 3 тим, що громадянське суспільство сьогодні задіяно на багатьох різних аренах [5; 6]. Коментарі щодо цього феномену знаходимо як серед лівих, так і серед правих. 3 одного боку, ліві бачать спільноту як «протиотруту» надмірній i нестримній жадібності та корисливим інтересам, що є ознаками сучасного суспільства, ліками від індивідуалізму. Тим часом, праві бачать спільноту як шлях до відновлення 
основних американських цінностей, яких колись дотримувалися, але зараз вони знаходяться під загрозою.

Отже, громада стала однією 3 домінуючих тем в житті демократичних суспільств. Різні дослідники зосереджуються на різних аспектах, утім, наукові пошуки Дж. Гарднера вражають ясністю та переконливістю. Автор вважає, що почуття спільності, яке може бути похідним від багатьох різних рівнів людського об’єднання від сусідства до робочої групи, може створити корисну посередницьку структуру між індивідом та суспільством. Дж. Гарднер пише: «У нашій системі «загальне благо» - це, перш за все, збереження системи, в якій усі види людей можуть - у рамках закону - реалізувати своє різноманітне бачення загального блага $\mathrm{i}$ водночас досягати таких видів взаємного пристосування, які роблять суспільну систему придатною для життя та працездатною. Гра суперечливих інтересів у рамках спільних цілей - це драма вільного суспільства» [6, с. 15]. Загальні цінності спільноти, на думку Дж. Гарднера, важливі, але він закликає визнати, що цілісність також повинна включати різноманітність.

Крім цих функцій, на думку Дж. Гарднера та інших фахівців, громада базується на турботі, довірі та команді, об’єднаних міцною та ефективною системою комунікацій та вирішення конфліктів. Інтерактивна природа спільноти $є$ посередником між особою та колективом.

Р. Кантор, відома дослідниця з менеджменту, коментує цю ідею в деяких своїх ранніх роботах, присвячених громадянському суспільству. Вона пише: «Пошук спільноти - це також пошуки напрямку та мети у колективному закріпленні особистого життя. Інвестування себе в спільноту, прийняття іï авторитету та готовність підтримувати іï життя можуть запропонувати ідентичність, особистий сенс та можливість зростати з точки зору стандартів та керівних принципів, які, на думку члена, виражають його власну внутрішню суть» [7, с. 73].

Здається, люди розчаровані у представницькій владі, вони відходять від політичних процесів і стають все більш ізольованими у своїх приватних просторах. Саме в цих умовах для подолання відповідного кризового стану в авангарді має постати громадянське суспільство.

3 іншого боку, громадяни все ще хочуть діяти. Вони пишаються своїми громадами та своєю країною i хочуть допомогти досягти позитивних змін. Насправді, багато громадян починають займатися політичною діяльністю нового типу, не витрачаючи свій час на виборчу чи партійну політику, яку вони вважають закритою та непроникною, а беруть участь у масових громадянських рухах у районах, робочих групах та асоціаціях. Ця діяльність є лабораторіями громадянства, аренами, де люди прагнуть налагодити нові відносини один 3 одним та ширший політичний лад, відносини, що усвідомлюють дилеми участі, які накладає сучасний світ, але також знають про нові можливості активізму та залучення, яке пропонують 
сучасні умови [8].

Схоже, що уряд також відіграє важливу роль у заохоченні побудови громад та громадянського суспільства. Цікаво, що багато прогресивних i перспективних громадських та політичних лідерів усвідомлюють важливість та життєздатність таких зусиль і самі залучаються до цього. Політичні лідери значною мірою звертаються до громадян як за допомогою сучасних інформаційних технологій, так і більш традиційними засобами. Так само, державні менеджери переосмислюють свою роль щодо залучення громадян до процесу урядування [9]. Знову ж таки, як зазначають Ш. Кінг та К. Стіверс, уряд може відігравати важливу та вирішальну роль у створенні, сприянні та підтримці зв’язків між громадянами та їх громадами [10].

Організаційний гуманізм та нове публічне адміністрування.

За останні тридцять років теоретики державного управління приєдналися до колег з інших дисциплін, припустивши, що традиційні ієрархічні підходи до соціальної організації $\epsilon$ обмежувальними 3 огляду на поведінку людей, i вони приєдналися до критики бюрократії та пошуку альтернативних підходів до керівництва та організації. У сукупності ці підходи прагнуть таких публічних організацій, в яких менше переважають питання влади і управління та більш уважно ставляться до потреб і проблем внутрішніх та зовнішніх компонентів.

Так само, як Р. Даль і Д. Волдо контрастували з пануючою точкою зору теорії державного управління, К. Аргіріс та Р. Големб'євський були протиріччям до пануючого погляду на організаційний менеджмент у другій половині XX століття. У книзі «Особистість та організація» К. Аргіріс досліджував вплив традиційних управлінських практик на психологічний розвиток людей у складних організаціях. Учений зауважив, що дослідження людської особистості показали, що люди, які ростуть від дитинства до дорослого віку, переходять від пасивності до активності, від залежності до незалежності, від обмеженого діапазону поведінки до більш широкого діапазону, від неглибоких до більш глибоких інтересів, від коротших до більш тривалих перспектив, від підлеглої позиції до позиції рівності чи надпорядкування та від недостатньої обізнаності до більшої обізнаності [11].

Для того, щоб сприяти індивідуальному зростанню, а також покращити організаційні показники, К. Аргіріс шукав такий підхід до управління, в якому менеджери мали б розвивати та використовувати «...навички самосвідомості, ефективного діагностування, допомагаючи людям рости та ставати більш творчими i менш залежно-орієнтованими...» [12, с. 213]. Учений зосередився на пошуку шляхів, якими організації могли б рухатися в цьому напрямку за допомогою програм запланованих змін, відомих як «розвиток організації».

У своїй ранній роботі «Люди, менеджмент та мораль» Р. Големб'євський розробив критику традиційних теорій організації з їх наголосом на повноваженнях зверху, ієрархічному контролі та стандартних операційних процедурах, 
стверджуючи, що такі підходи відображають нечутливість до моральної постави особистості, зокрема у питанні свободи особистості. На противагу цьому, Р. Големб’євський шукав спосіб «розширити область розсуду, відкритого для нас в організації, та збільшити індивідуальну свободу» [13, с. 305].

Слідуючи перспективі організаційного розвитку, Р. Големб'євський закликав менеджерів створити відкритий клімат для вирішення проблем через організацію, щоб члени могли протистояти проблемам, а не боротися або тікати від них. Він спонукав вибудовувати довіру між окремими людьми та групами у всій організації, доповнювати або навіть замінювати авторитет ролі чи статусу авторитетом знань та компетентності. Він запропонував, щоб відповідальність за прийняття рішень та вирішення проблем розташовувалася якомога ближче до джерел інформації, а конкуренція, де вона існує, сприяла досягненню робочих цілей. Він наполягав на тому, щоб максимально розширити співпрацю між окремими особами та підрозділами, робота яких взаємозалежна, та розробити системи винагород, які визнають як досягнення місії організації, так і зростання та розвиток іiі членів. Менеджери повинні працювати, для того, щоб підвищити самоконтроль та самонаправлення людей у організації, створити умови, за яких конфлікт виявляється та керується належним чином й позитивно, а також для підвищення обізнаності про груповий процес та його наслідки для результативності.

Слід зазначити, що нове публічне адміністрування внесло інші несподівані точки зору до масової дискусії щодо державного управління. Зокрема, з'явився аргумент щодо того, щоб адміністратори відігравали більш активну роль у розвитку державної політики, ніж це було раніше, частково тому, що складність сучасних проблем вимагала досвіду професійно підготовлених адміністраторів та пов'язаних 3 ними технічних спеціалістів, а частково просто тому, що "хтось повинен вирішувати виклики". 3'явилося більш чітке визнання та обговорення ролі цінностей у державному управлінні. Наприклад, Дж. Фредеріксон у роботі «Нове публічне адміністрування» стверджував від імені соціальної справедливості як керівного концепту у прийнятті адміністративних та політичних рішень: «Державний службовець зобов'язаний вміти розробляти та захищати критерії та заходи справедливості та розуміння впливу державних послуг на гідність та добробут громадян» $[14$, с. 46]. По суті, забезпечення справедливого вирішення суспільних проблем передбачає не просто пропонування однакових послуг усім, а більш високого рівня послуг тим, хто цього найбільше потребує. Дж. Фредеріксон стверджує, що державне управління не є нейтральним i, безумовно, не повинно оцінюватися лише за критерієм ефективності. Такі поняття, як рівність, справедливість та чуйність також повинні залучатися.

Постмодернізм.

Наприкінці шістдесятих - на початку сімдесятих років вчені з державного 
управління почали більш критично досліджувати підхід до здобуття знань, що лежить в основі основної раціональної моделі управління. Основою для цього дослідження стала ідея про те, що державне управління, як і інші суспільні науки, стало залежним від певного підходу до здобуття знань - позитивізму - i що цей підхід тонко, але різко обмежує діапазон мислення, можливого у цій галузі. Відповідно, факти суспільного чи організаційного життя можна відокремити від цінностей. Роль науки полягає в тому, щоб зосереджуватись на фактах, а не на цінностях. Факти можна спостерігати та вимірювати так само, як поведінку фізичних або хімічних елементів.

Критики позитивізму зазначали, що опора на позитивістську модель посилила тенденції до об’єктивації та деперсоналізації, які стали частиною масової моделі державного управління. У пошуках альтернатив деякі вчені звернулися до інтерпретаційних підходів до здобуття знань, підходів, які зосереджувались на розумінні сенсів, які люди вносять у свій досвід, особливо той досвід, яким вони діляться 3 іншими. Інші звернулися до критично важливого дослідження сил, які лежать в основі людського досвіду, особливо тих сил влади та панування, які спотворюють комунікації між людьми. За допомогою таких підходів вчені сподівалися побудувати альтернативні шляхи до вивчення та практики державного управління, альтернативи, більш чутливі до цінностей (не лише до фактів), до суб'єктивного людського сенсу (не лише до об'єктивної поведінки), і до повного спектру емоцій та почуттів, пов’язаних із стосунками між реальними людьми.

Більшість постмодерністів стверджують, що проблема, з якою ми стикаємось сьогодні, полягає в тому, що ми втратили здатність сказати, що є справжнім. Усі раніше сприйняті «світогляди», а також «наукові пояснення», які, здавалося, працювали в минулому, мали фатальні вади, більшість з яких пов'язані з тим, що ці пояснення були результатом конкретного місця та певного часу, i вони могли звертатися до світу лише з цієї переважно унікальної точки зору.

Постмодерністські теоретики державного управління мають центральну прихильність до ідеї «дискурсу», уявлення про те, що суспільні проблеми, швидше за все, вирішуються за допомогою дискурсу, ніж за допомогою «об'єктивних» вимірювань або раціонального аналізу [15]. Ідеал автентичного дискурсу передбачає повну взаємодію адміністраторів та громадян, не просто як раціонально зацікавлених особистостей, яких збирають разом, щоб розмовляти, а як учасників відносин, у яких вони взаємодіють один з одним як люди. Результат процесу переговорів та досягнення консенсусу - це процес, коли індивіди взаємодіють один 3 одним, повністю охоплюючи всі аспекти людської особистості, не просто раціональні, а досвідні, інтуїтивні та емоційні.

Висновки. Виходячи з вище висвітлених ідейних настанов, Дженет та Роберт Денхардти розробляють сім принципів нової публічної служби: 1) служити 
громадянам, а не клієнтам; 2) шукати суспільні інтереси; 3) цінити громадянство вище за підприємництво; 4) мислити стратегічно, діяти демократично; 5) визнавати, що питання підзвітності непросте; 6) служити більше, ніж скеровувати; 7) цінувати народ, а не лише продуктивність [16]. Практичне втілення цих принципів сприятиме узгодженню системи публічного управління та адміністрування 3 вимогами часу та потребами суспільства, а також технологічними можливостями й світовими тенденціями.

\section{Лimepamypa:}

1. Barber B. Strong Democracy: Participatory Politics for a New Age. Berkeley: University of California Press, 1984.

2. Mansbridge J. Public Spirit in Political Systems. In Values and Public Policy, ed. Henry J. Aaron, Thomas Mann, and Timothy Taylor. Washington, DC: Brookings Institution, 1994. P. 146-72.

3. Sandel M. Democracy's Discontent. Cambridge: Belknap Press of Harvard University Press, 1996.

4. Turner B. Citizenship and Social Theory. London: Sage, 1993.

5. Etzioni A. The New Communitarian Thinking. Charlottesville: University of Virginia Press, 1995.

6. Gardner J. Building Community. Washington, DC: Independent Sector, 1991.

7. Kantor R. Commitment and Community. Cambridge, MA: Harvard University Press, 1972.

8. Boyte H., Kari N. Building America. Philadelphia: Temple University Press, 1996.

9. Thomas J. Public Participation in Public Decisions. San Francisco: Jossey-Bass, 1995.

10. King Ch., Stivers C. Government Is Us: Public Administration in an Anti-Government Era. Thousand Oaks, CA: Sage, 1998.

11. Argyris Ch. Personality and Organization. New York: Harper and Row, 1957.

12. Argyris Ch. Interpersonal Competence and Organizational Effectiveness. Homewood, IL: Dorsey Press, 1962.

13. Golembiewski R. Men, Management, and Morality. New York: McGraw-Hill. 1967.

14. Frederickson H. New Public Administration. Tuscaloosa: University of Alabama Press, 1980.

15. McSwite O. Legitimacy in Public Administration. Thousand Oaks, CA: Sage, 1997.

16. Denhardt R. The New Public Service. Serving, not steering. New York, Business Park Drive, 2007. $240 \mathrm{p}$.

\section{References:}

1. Barber, B. (1984). Strong Democracy: Participatory Politics for a New Age. Berkeley: University of California Press.

2. Mansbridge, J. (1994). Public Spirit in Political Systems. In Values and Public Policy, ed. Henry J. Aaron, Thomas Mann, and Timothy Taylor. Washington, DC: Brookings Institution. P. $146-72$.

3. Sandel, M. (1996). Democracy's Discontent. Cambridge: Belknap Press of Harvard University Press.

4. Turner, B. (1993). Citizenship and Social Theory. London: Sage.

5. Etzioni, A. (1995).The New Communitarian Thinking. Charlottesville: University of Virginia Press.

6. Gardner, J. (1991). Building Community. Washington, DC: Independent Sector.

7. Kantor, R. (1972). Commitment and Community. Cambridge, MA: Harvard University Press.

8. Boyte, H. \& Kari, N. (1996). Building America. Philadelphia: Temple University Press. 
9. Thomas, J. (1995). Public Participation in Public Decisions. San Francisco: Jossey-Bass.

10. King, Ch. \& Stivers C. (1998). Government Is Us: Public Administration in an AntiGovernment Era. Thousand Oaks, CA: Sage.

11. Argyris, Ch. (1957). Personality and Organization. New York: Harper and Row.

12. Argyris, Ch. (1962). Interpersonal Competence and Organizational Effectiveness. Homewood, IL: Dorsey Press.

13. Golembiewski, R. (1967). Men, Management, and Morality. New York: McGraw-Hill.

14. Frederickson, H. (1980). New Public Administration. Tuscaloosa: University of Alabama Press.

15. McSwite, (1997). O. Legitimacy in Public Administration. Thousand Oaks, CA: Sage.

16. Denhardt, R. (2007). The New Public Service. Serving, not steering. New York, Business Park Drive. 240 p. 